\title{
Th1 Cell/Th2 Cell Ratio Measurement
}

National Cancer Institute

\section{Source}

National Cancer Institute. Th1 Cell/Th2 Cell Ratio Measurement. NCI Thesaurus. Code C129775.

The determination of the ratio of type $1 \mathrm{~T}$ helper cells (Th1) compared to type $2 \mathrm{~T}$ helper cells (Th2) present in a sample. 